IRA-International Journal of Management \& Social Sciences

ISSN 2455-2267; Vol.05, Issue 01 (2016)

Pg. no. 159-174

Institute of Research Advances

http://research-advances.org/index.php/RAJMSS

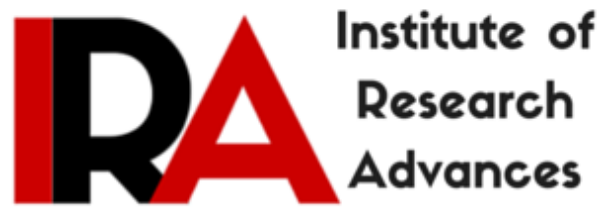

\title{
A Study to Understand the Factors that Play Major Role in Influencing the Loyalty Behaviour of Shoppers towards Department Based Brick-and-Mortar Fashion Retailers with Special Reference to Pune City, India
}

\author{
${ }^{1}$ Dr. Sarita Karangutkar \\ Assistant Professor \\ VMV Commerce, JMT Arts \& JJP Science College, Nagpur, India. \\ ${ }^{2}$ Prof. Prashant Chaudhary \\ Assistant Professor \\ Sinhgad Institute of Management \& Computer Application (SIMCA), Pune, India. \\ ${ }^{3}$ Siddhant Shah \\ Sinhgad Institute of Management \& Computer Application (SIMCA), Pune, India.
}

Type of Review: Peer Reviewed.

DOI: http://dx.doi.org/10.21013/jmss.v5.n1.p16

\section{How to cite this paper:}

Karangutkar, S., Chaudhary, P., \& Shah, S. (2016). A Study to Understand the Factors that Play Major Role in Influencing the Loyalty Behaviour of Shoppers towards Department Based Brick-and-Mortar Fashion Retailers with Special Reference to Pune City, India. IRA-International Journal of Management \& Social Sciences (ISSN 2455-2267), 5(1), 159-174. doi:http://dx.doi.org/10.21013/jmss.v5.n1.p16

(C) Institute of Research Advances

\section{(cc) BY-NC}

This work is licensed under a Creative Commons Attribution-Non Commercial 4.0 International License subject to proper citation to the publication source of the work.

Disclaimer: The scholarly papers as reviewed and published by the Institute of Research Advances (IRA) are the views and opinions of their respective authors and are not the views or opinions of the IRA. The IRA disclaims of any harm or loss caused due to the published content to any party. 


\begin{abstract}
The major objective of this study is to understanding the factors that influence the loyalty behaviour of customers towards brick-and-mortar departmental fashion retailers in Pune city. The study has been conducted by keeping one of the leading departmental stores in reference, but the findings of the study are generalized and can be applied to other fashion retailers of similar or non-similar formats. Fashion is one of the fastest growing categories and continues to grow at exponential growth rate due to increased fashion awareness and aspirations. Today we can see that fashion products account for a substantial percentage of the products sold across a broad range of merchandise categories.

Research on fashion retailing has been based on varying conceptual definitions of the construct and has focused primarily on in-store retailing. A number of researchers have made important contributions to understanding of loyalty behaviour of shoppers towards fashion retailers. Therefore, the consumer behaviour of an important sector of the millennials is worth to be researched. Here the researchers are trying to understand the variables that influence shoppers' loyalty behaviour which is nothing but the "preferential" behaviour of the shoppers towards a specific retailer's stores. During this research the researchers found that, some of the major influencing factors are shopping atmosphere-ambience, fashion image of the retailer (retailer as a brand), fashion image of the Private Labels, and the effectiveness of the loyalty programme offered by the retailer.
\end{abstract}

Keywords- Fashion retailing, Private label brands, visual merchandising, store ambience, loyalty behaviour etc.

\title{
Introduction-
}

A fashion brand essentially includes the names, terms, signs, symbols and logos that identify the fashion products and companies. In today's fashion retailing context the "brand value" is not just a financial number but it is a measure of several factors like loyalty of customers, the ability of a brand to keep offering newer products and technology, and the connect with consumers, who give it a preference or premium. Today Consumers have become more demanding forcing retailers to reinnovate and include various new components to their marketing programme. Here the retailers are not only expected to include these elements but also to integrate them in order to create right shopping experience. Now retailers can use various tools which allow them to collect quantitative and qualitative data (big data) from the consumers and thus apply these insights into their business strategy. Here the objective should be offer the retail experiences to win your customer's hearts, the new technologies also allow retailers to offer new and exciting in-Store purchase experiences. So we can find that retailers are increasingly focusing on integrating all these elements, to blend the best in online and offline, for the purpose of keeping and making clients loyal, optimizing their visit and improving their overall shopping experience. The goal is to unlock the right fashion value and make the brick-and-mortar fashion retailing a stronger proposition in the face of increased competition from online fashion retailers.

Hence the brand image of a fashion retailer comprises of a bundle of promises on the company's part and expectations on the consumer's part that have been met. If a customer perceives a higher value in a brand, she will be ready to give preference or ready to pay a premium for it. Hence the degree of loyalty behaviour of consumers towards a fashion retailer's store helps the marketers to understand how their brand is moving along with other brands and whether it is able to keep pace. They can accordingly decide on the various decisive factors that play major role in today's fashion retailing scenario. Here the researchers have assumed that the three factors- right shopping ambienceatmosphere, strong private label brands and effective loyalty programmes enhance the perceived fashion image of a fashion retailer that eventually leads to increased brand loyalty. Here the brand loyalty in the form of preference given by the consumers to the brick-and-mortar stores of a specific fashion retailer. In order to make the study more focused here the researchers has taken the department based fashion retailers and the survey was conducted in Pune city. The survey is store based survey and it acts an anchor for the general consumer behaviour while patronising a specific store. 


\section{Brick-and-mortar retailing-New challenges and strategic assets}

Today we can see that, online shopping is an increasing phenomenon today. Online marketplaces are increasingly aiming to attract and retain their buyers and simultaneously acquiring a better understanding of the shopping behaviour of the customers through a secured and user-friendly website, efficient customer service and an engaging marketing programme.

On the other side, consumers relying primarily on mobile, laptops and desktops to order fashion products, the face of retail is changing at an incredible speed today and this change is imperative for business. Priya Sachdev, Founder, RockNShop in her article opines that delivering a truly seamless experience requires a presence at every stage of the customer journey, from discovery through research, purchase, fulfilment and beyond, to product maintenance or returns. To achieve this, retailers must also integrate their operations in tandem with the current needs. This does not mean that brick-and-mortar store is dead! She further argues that the touch-feel-try shopping experience provided by the brick-and-mortar players is a powerful asset when it comes to creating a complete shopping experience. Here the trick is to connect the touch points along the consumers' purchase journey and focus specifically on how to support their digital shopping experience once they enter the doors of the store.(Sachdev, 2016)

\section{Literature Review-}

According to a paper presented at the annual meeting of the Canadian Communication Association and the Canadian Political Science Association under the aegis of the University of Victoria, British Columbia (2013) on Justin Trudeau (current Prime Minister of Canada) and political branding, "An image is the evoked impression of an entity formed from the recall of all communication impressions; a brand is an evoked image that resonates on an emotional level and which stimulates customer loyalty."(Narasimhan, 2016)

Steuart Henderson Britt in his book titled-Consumer Behaviour and the Behavioural Sciences: Theories and Applications, defines brand image as the sum of total of impressions the consumer receives from many sources: from actual experience and hearsay about the brand itself as well as its packaging, its name, the company making it, the types of people the individual has been using the brand, what is said in its advertising, as well as from the tone, format, type of advertising vehicle in which the product story was told. This implies, from a general perspective, that a brand is more than a visual label for differentiation and includes an imagery mean. In today's highly cluttered marketplace, a brand image is challenged by many factors as more and more brands are being observed and exposed by various media channels.(Britt, 1967)

As far as department store is concerned, the research on consumer loyalty behaviour in retail could be classified into two categories. One is where the researchers have focused on fashion retailing and the other is non-fashion categories. According to (Leszczyc, Sinha, \& Timmermans, 2000) consumers are facing constantly changing retail scenario. They have to constantly decide whether they would stay loyal or try new formats or go for discounts to suit their convenience.

Joseph H. Hancock in his book titled- Brand/Story Ralph, Vera, Johnny, Billy, and Other Adventures in Fashion Branding, has examined how a retailer, manufacturer, or designer label grabs an individual's interest. Hancock has opined that fashion branding is not just about specific products. He argued that for consumers, branding tells the story and creates the identity for a product, a person, and a company. Interpreting the term brand to the fashion industry, fashion branding can be seen as the context that surrounds the garment as well as the image that designers, retailers, manufacturers and promotional consultants create in order to encourage consumers to buy new items. Hancock also states that a fashion brand offers an overall experience that is unique, different, special and identifiable. Branding is also seen as a competitive strategy that targets customers with products, advertising and promotion in order to encourage purchase and repurchase of products from the company(Hancock, 2009). 


\section{Private Label Brands-}

Govind Shirkhande, Customer Care Associate and MD - Shoppers Stop Ltd, in interview opined that, a private brand provides retailers a distinct differentiation from the crowd. With private label brands, retailers have full control on design, pricing, merchandise assortment, stocking, and distribution. By studying customers' shopping habits and preferences as well as global fashion trends, retailers are able to immediately inject these insights into their brands to improve their productivity. Finally, private brands give retailers a higher margin. He further added that, private label brands have an edge with regards to understanding the customers better, especially those that have a loyal set of customers attached to them. Shoppers Stop have private brands such as Stop, haute curry, Kashish, Life, Elliza Donatein and Vettorio Fratini-each of these have USPs and a brand story/ positioning that set it apart from the national/international brands. By means of data analytics fashion retailers today are in a better position to narrow down on merchandise and products that sell well than the others and also the trends that are in vogue. At the end of the interview he concludes with the argument that, Private brands are a great way to differentiate a department based fashion retailer from the competition. When given the right treatment, fashionable private brands can be vehicles of customer loyalty. He says that Shoppers Stop have many customers who have been consistently shopping with the department chain owing to their affinity for our private brands. So, it is a huge opportunity for retailers like them.(Shirkhande, 2016)

Similarly Manoj Gupta, Founder and CEO, Craftsvilla.com stated that, Private labels are an opportunity to create branding in a category which does not have any strong existing brands - a largely unbranded category like ethnic wear. They offer lower prices to consumers while supplying products that are similar in quality and design to known brands. They also have a higher margin as compared to marketplace commission.(Gupta, 2016)

Prashant Chaudhary argues that, Private Labels when developed strategically in line with the brand image of the fashion retailer; can create an impeccable persuasive connection with consumers, drawing them into a retail store, but more importantly, becoming an essential, preferential experiential and indispensable lifestyle choice that they embrace over the long-term. Here the researcher has stated the seven perspectives of retailers towards the private labels which are-Profitability, Positioning, Preference, Proposition \& differentiation, Placement (merchandise shelf space and place), Power of bargaining vis-a-vis national brands and Patronage perspective. He further added that, in the context of burgeoning growth in e-tailing we can find many instances where private labels have surpassed a national brand's capacity to deliver on visibility, consumer interest, appeal and involvement.(Chaudhary, 2015)

\section{Store Ambience and atmospherics-}

Phillip Kotler was the first to use and define the term "atmospherics" as "the conscious designing of space to create certain effects in buyers. He categorically stated that atmospherics is the effort to design buying environments to create specific emotional effects in the buyer that enhance his purchase probability (Kotler, 1973). In the literature regarding the store atmospherics and its impact on consumer perception and loyalty behaviour many articles examine the impact of these factors on the overall shopping experience. Reactions to retail environments, however, are not universal. Different categories of consumers appear to behave differently when presented with the same atmospheric stimulus.(Areni \& Kim, 1993; Turley \& Milliman, 2000; Wilson, 2003)

Thus, to consolidate the knowledge gained in this area and to encourage additional research, this article presents a review of the literature stream that attempts to further the theoretical and empirical understanding of atmospheric influences on loyalty behaviour of the consumers in Pune city with special reference to fashion shopping at brick-and-mortar stores.

Today many retail marketers view the store environment-ambience as increasingly important to meet the expectations of their customers by providing a positive total shopping experience and used as a communication channel for creating the desired positioning of the store in the consumers' mind. 
(Levy, Weitz, \& Pandit, 2008) In a competitive market, marketing researchers realise that if consumers are influenced by physical stimuli experienced at the point of purchase, then the practice of creating influential atmospheres should be an important marketing strategy for most exchange environments. (Turley \& Milliman, 2000) According to the existing research specifically in the field of fashion retailing atmospheric planning can make the difference between business success and failure. (Bitner, 1992)

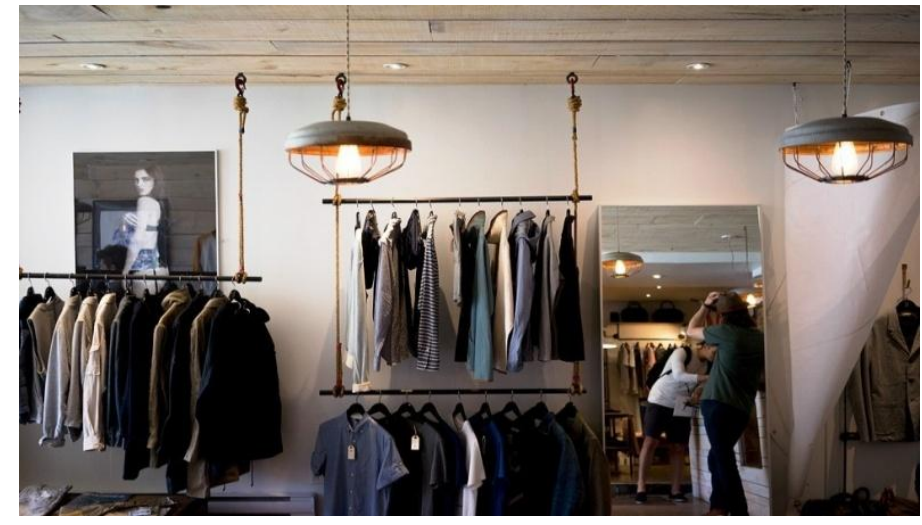

Figure 1- Store Ambience accentuates the "Fashion Image" of the retailer (Sourcehttps://pixabay.com/en/clothing-store-shop-boutique-984396/)

Physical shopping environments that are coupled with creative visual merchandising influence all aspects of the brick-and-mortar retailing business, including aspects such as the customer's decisions on where to go for shopping, consumer's perceptions of store image, quality-assortment of merchandise and service level, buyers behaviours of the amount of time and money spent at the store, in fact the consumer's overall satisfaction with the retail store.(Bellizzi \& Hite, 2006; Machleit, Kellaris, \& Eroglu, 1994)

Here we can also quote the study conducted by Prashant Chaudhary and Rahul Jadhav regarding the impact of Visual merchandising on consumer buying behaviour in Pune city. In this study, the researchers found that most of the tools of visual merchandising significantly influence customers' buying behaviour. Retailers should continuously reinforce their usage to create favourable shopping environments to influence customers' both in-store responses and future store choice decisions. They further stated that, everything the retailers do in the store must fit into the image they chose to create. This will lead to creation of a recognizable image that will be applied and communicated effectively through multiple media to gain customer recognition and loyalty.(Chaudhary \& Jadhav, 2014)

Therefore, retail environments should be crafted with a particular consumer in mind. This probably means that department based retail stores or smaller specialty stores, usually aimed at narrower target markets are more likely to be able to induce more consistent behaviour from consumers. (Turley \& Milliman, 2000)

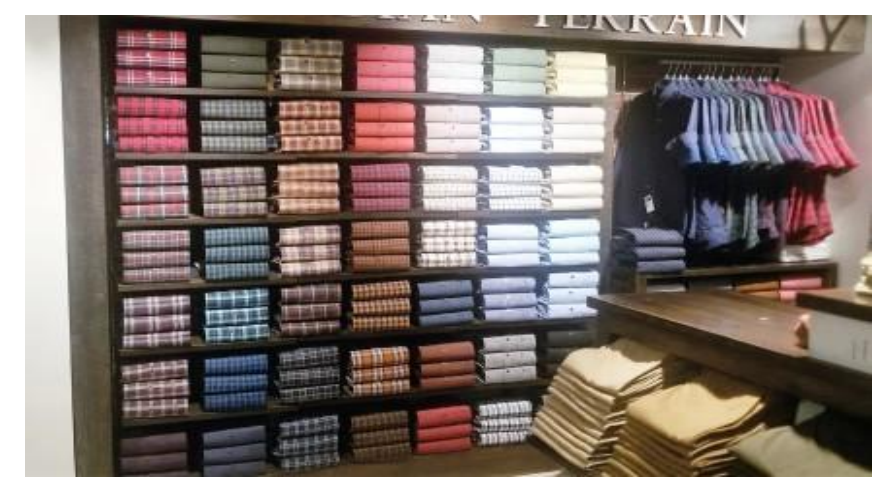

Figure 2- Visual Merchandising \& Store Display (Image Courtesy- Siddhant Shah) 


\section{Loyalty Programme-}

Today loyalty programmes are seen as the essence of any business processes of identifying, maintaining, and increasing the yield from major accounts or best customers achieved by building valuable relationships with them (Buttle, 1996). Russell Lacey, Julie Z. Sneath opined that, customer loyalty programs are designed to enhance the growth of the marketing exchange between preidentified customers and a brand or firm. The point of differentiation of these programmes from other promotions is their long-term nature, retailer' efforts to retain customers, and consumers' resulting higher purchasing frequency. They further argued that, Loyalty programs can induce customers to give up their personal information in exchange for benefits they would not otherwise receive. Marketers use the higher level of benefits available through loyalty programs as a form of compensation to customers for sharing personal information (Lacey \& Sneath, 2006; Mägi, 2003). Byron Sharp and Anne Sharp found that, the extension to a different market with an identical loyalty program has shown that the lack of product or price differentiation enhances the loyalty program's excess loyalty effect (Sharp \& Sharp, 1998). This naturally applies to the nature of business most department based fashion retail chain follows.

Raghava Rao Gundala, Arthur Lok Jack and Richard Ronald Gomes have argued that even though loyalty programs are regarded as a justifiable component of the marketing strategy and an integral part of retailing, it would appear that they achieve little more than spurious loyalty. However, when these programs are considered as an integrated component within a marketing programme, they may begin to make a valuable contribution in developing sustainable loyalty. This seems to be the viable and long-term role for loyalty programmes and they are likely to be in marketers' agenda for a long time (Gundala, Jack, \& Gomes, 2012). Byung-Do Kim, Mengze Shi and Kannan Srinivasan opined that Reward programme is a promotional tool to develop customer loyalty, offer incentives to consumers on the basis of cumulative purchases of a given product or service from a firm. They proposed that loyalty programs would restrict and eventually deaden the desire to switch to another retailer because of the high cost of switching.(Kim, Shi, \& Srinivasan, 2001)

Neil Davey in his blog titled- Emotional vs. transactional loyalty: Is it more important to win hearts or minds? - has briefly explained the difference between rational and emotional loyalty. He states that, rational loyalty is where the customer weighs up the value of the product or service to make a calculated decision about the relationship with the brand. Whereas in case of emotionally loyal customers are willing to spend with the brand even if meaningful and available alternatives are presented. In light of this, he further argued that, it is therefore perhaps surprising to see that loyalty programmes are almost universally aimed towards transaction-based rewards and rational loyalty, as opposed to developing emotional attachment with the customers.(Davey, 2014)

Prashant Chaudhary in his book titled-Retail Marketing in the modern age argues that, the effective loyalty programmes should create incentives that are beneficial to customers and are easy to redeem. They should go beyond point accumulators to actually purchases and eventually to engaging them (members of the loyalty programme) as well. When the loyalty programme starts engaging the customers, they can convert them into advocates of the brand or the company. He further stated that, endorsement by loyal customers is more powerful to their family and friends than any other advertisement campaign. The retailers with high loyalty from both external and internal customers are generally seen to outpace their competitors. (Chaudhary, 2016)

\section{Objectives of the study}

- To understand the factors influencing Loyalty behavior of shoppers towards the fashion retailers

- To gain insight on shopper's opinion on shopping experience provided by shoppers stop

- To study the Consumer behavior exhibited by shoppers for towards a brick-and-mortar department based fashion retailer 


\section{Scope of the study}

- This study focuses on the various factors that affect the loyalty behavior towards the department stores engaged in the business of fashion.

- This study is commissioned at the Shivaji Nagar store of Shoppers Stop, so there are some chances of biased responses.

- The respondents were the customers coming for Shopping at the above mentioned outlet during this research which is carried out from May 2016 to July 2016.

\section{$\underline{\text { Research Methodology }}$}

\section{Research design \& Data collection}

A descriptive research design is used in this study to describe the status of the different variable. Data was being collected for the research, analysis and synthesis of which provides the systematic information about the situation. Here the survey method is used for data collection for which a structured Questionnaire was constructed. Objective was to understand the buying behaviour of customers pertaining to fashion shopping and also to obtain insights regarding customer perception/expectation from department based fashion retail stores. This questionnaire comprised of dichotomous \& multiple choice question and perception was measured on Likert scale. As far as sampling method is concerned the non-probability sampling and convenience sampling method is used to serve the objective of this study in the given constraints. Here the population was all the consumers those shop at the brick-and-mortar fashion retail outlets in Pune city.

Sampling Unit: Customers visiting Shoppers Stop store located at Shivaji nagar, Wakadewadi, Pune.

Sample size: Questionnaire was filled from 150 consumers out of which 106 were considered for final analysis as they were workable.

\section{Data Analysis \& Interpretation}

Demographic Factors- Gender and Age of the respondents

\begin{tabular}{|l|l|l|}
\hline Gender & Number of respondents & Percentage \\
\hline Male & 77 & $73 \%$ \\
\hline Female & 29 & $27 \%$ \\
\hline Total & 106 & $100 \%$ \\
\hline
\end{tabular}

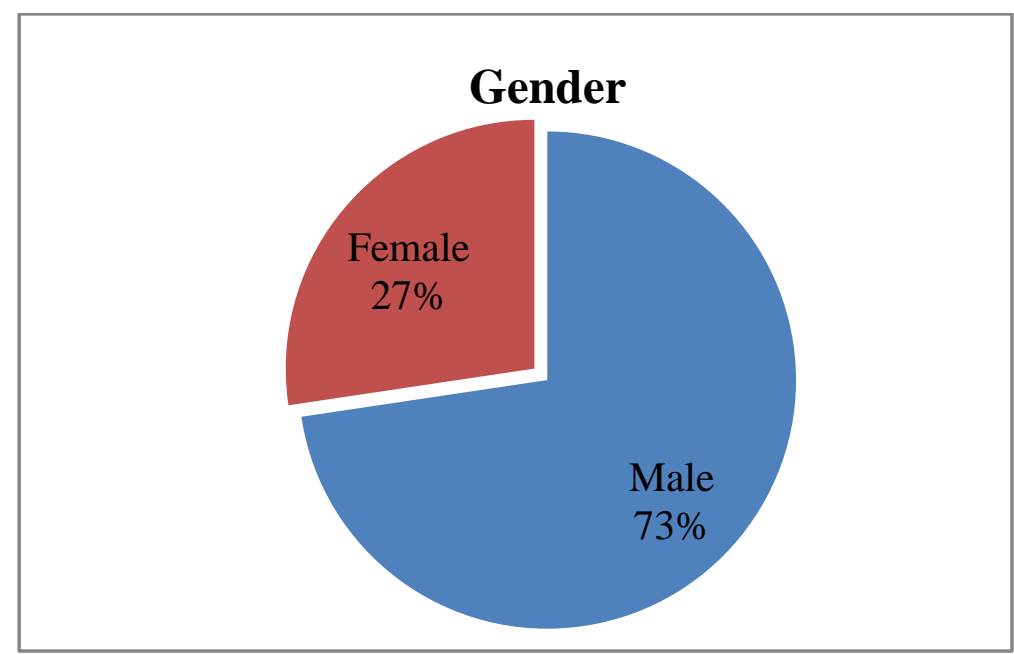


Inference: Researcher tried to ensure the equal participation of both men and women to avoid any kind of gender bias. However the number of male respondents was than that of female respondents

\begin{tabular}{|l|l|l|}
\hline AGE & No. of Respondents & Percentage \\
\hline $\mathbf{2 1 - 2 5}$ & 19 & $18 \%$ \\
\hline $\mathbf{2 6 - 3 0}$ & 16 & $15 \%$ \\
\hline $\mathbf{3 1 - 3 5}$ & 34 & $32 \%$ \\
\hline $\mathbf{3 6 - 4 0}$ & 13 & $12 \%$ \\
\hline $\mathbf{4 1 - 4 5}$ & 13 & $12 \%$ \\
\hline $\mathbf{4 6 - 5 0}$ & 3 & $3 \%$ \\
\hline $\mathbf{5 1 - 5 5}$ & 2 & $2 \%$ \\
\hline $\mathbf{5 6 - 6 0}$ & 3 & $3 \%$ \\
\hline $\mathbf{6 1 \&}$ more & 3 & $3 \%$ \\
\hline Total & $\mathbf{1 0 6}$ & $\mathbf{1 0 0 \%}$ \\
\hline & & \\
\hline
\end{tabular}

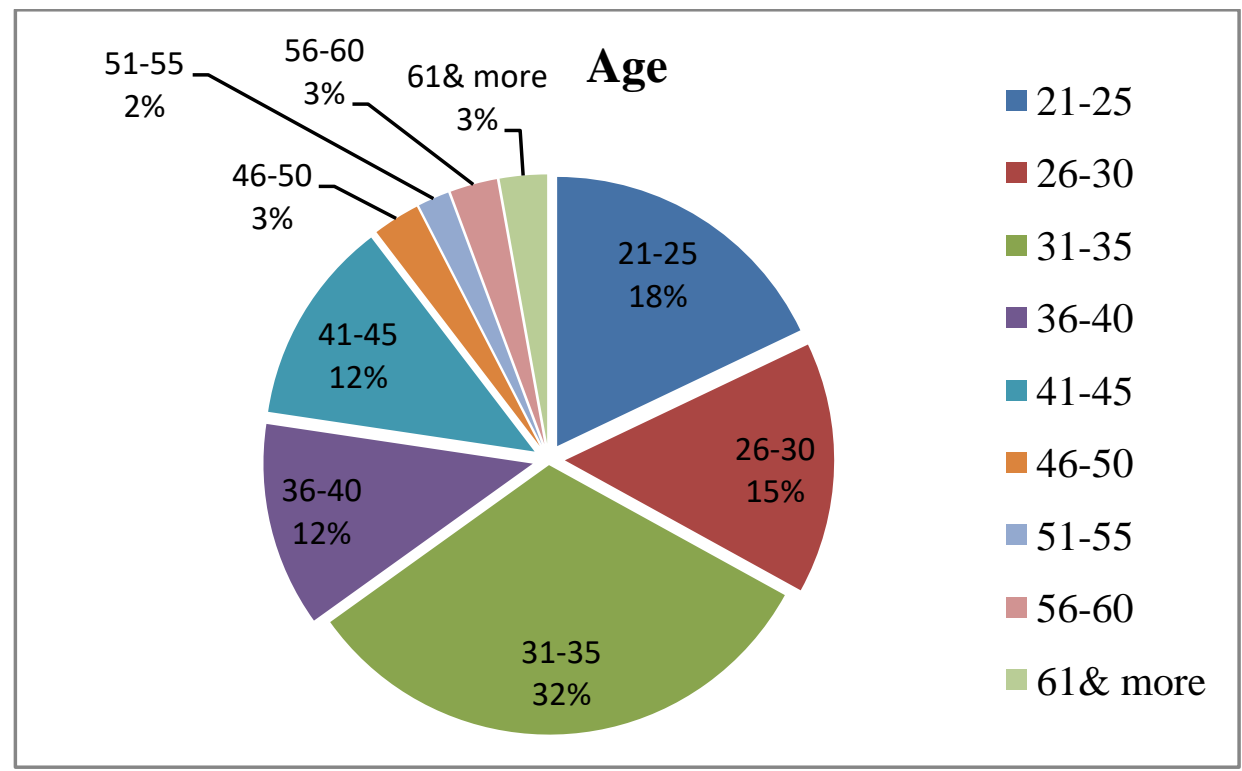

Inference: Most of the respondents were in the age group of $31-35$ years

1) About frequency of shopping

\begin{tabular}{|l|l|l|}
\hline Frequency of shopping & No. of Respondents & Percentage \\
\hline Once a Week & 0 & $0 \%$ \\
\hline Once a Fortnight & 0 & $0 \%$ \\
\hline Once a Month & 28 & $26 \%$ \\
\hline Once in 3 Months & 45 & $42 \%$ \\
\hline Once a 6 Months & 27 & $26 \%$ \\
\hline In a year & 6 & $6 \%$ \\
\hline Total & $\mathbf{1 0 6}$ & $\mathbf{1 0 0 \%}$ \\
\hline
\end{tabular}




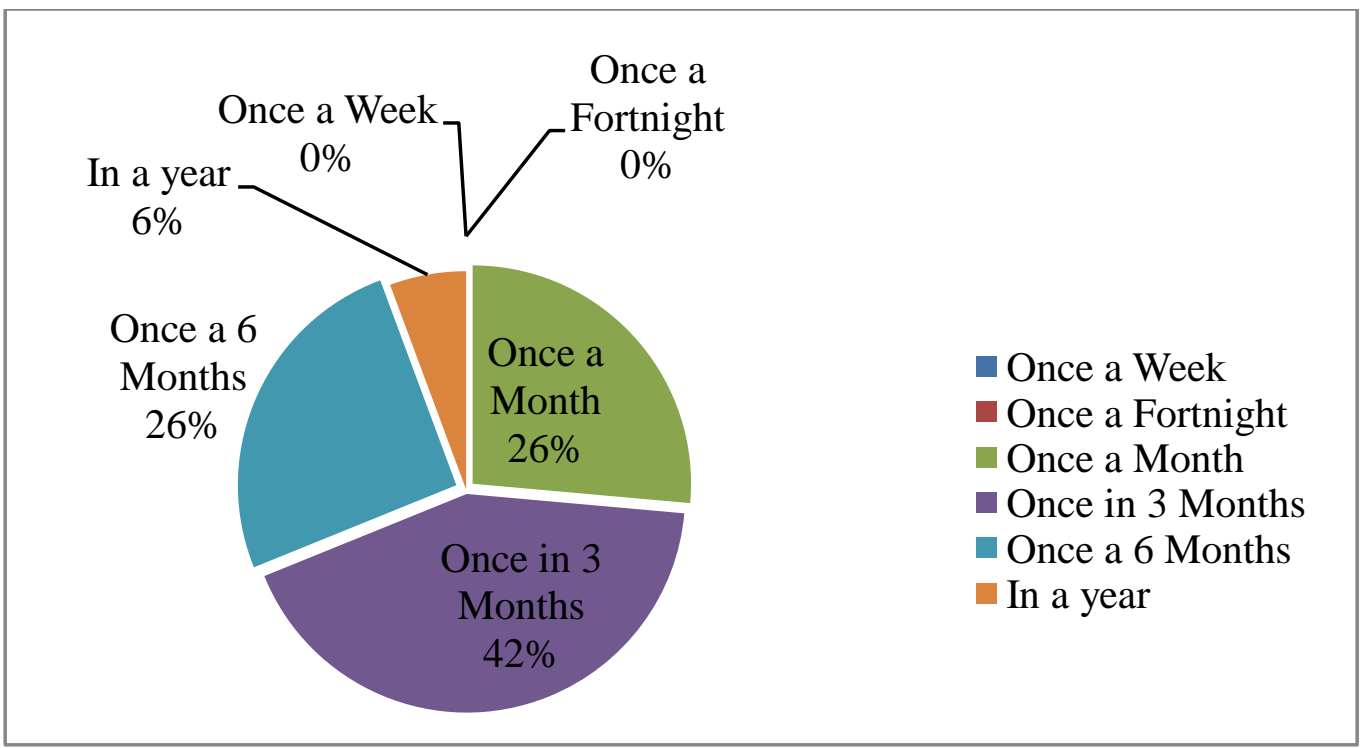

Inference: Majority of respondents tended to shop at a frequency of once in three months.

2) Do you shop at stores other that Shoppers Stop?

\begin{tabular}{|l|l|l|}
\hline Responses & No. of Respondents & Percentage \\
\hline Yes & 90 & $85 \%$ \\
\hline No & 16 & $15 \%$ \\
\hline Total & $\mathbf{1 0 6}$ & $\mathbf{1 0 0 \%}$ \\
\hline
\end{tabular}

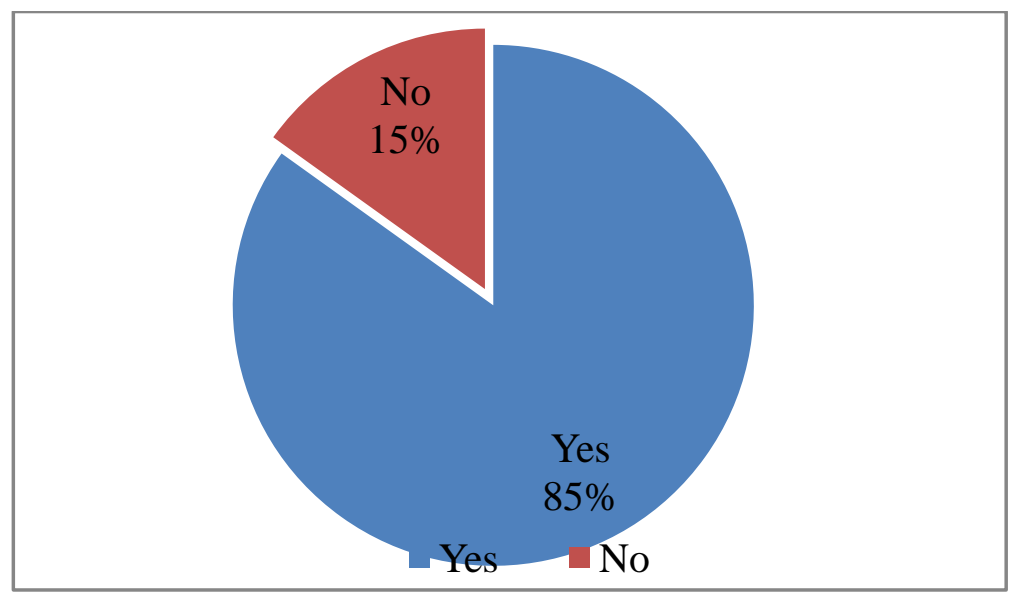

Inference: Majority number of respondents also shops at stores other than Shoppers Stop

3) If yes, which are the other department stores where you shop?

\begin{tabular}{|l|l|l|}
\hline Stores & No. of Respondents & Percentage \\
\hline Lifestyle & 60 & $67 \%$ \\
\hline Central & 20 & $22 \%$ \\
\hline Pantaloons & 10 & $11 \%$ \\
\hline Total & $\mathbf{9 0}$ & $\mathbf{1 0 0 \%}$ \\
\hline
\end{tabular}




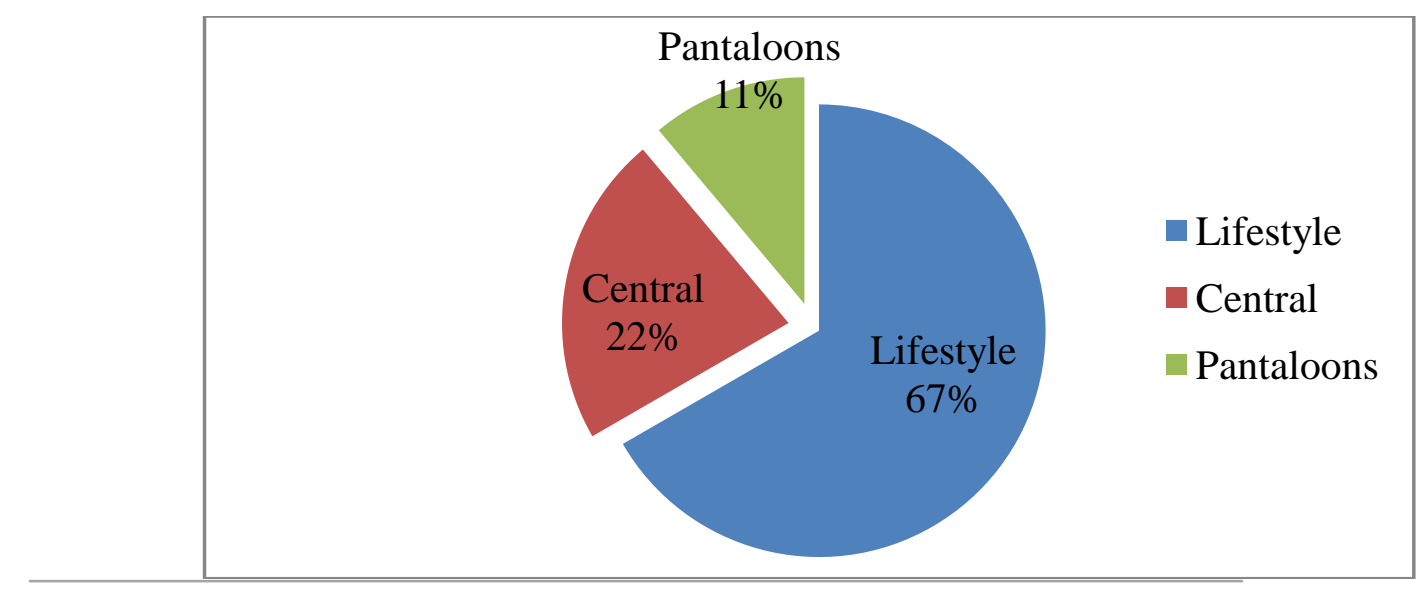

Inference: Lifestyle is the store visited by majority of respondents other than the stores of Shoppers Stop.

4) About occasions for shopping at Shoppers Stop

\begin{tabular}{|l|l|}
\hline Responses & Percentage \\
\hline Promotional Offers & $12 \%$ \\
\hline Shop on Regular Basis & $55 \%$ \\
\hline Special Occasions & $11 \%$ \\
\hline End of Season Sale & $22 \%$ \\
\hline Total & $\mathbf{1 0 0 \%}$ \\
\hline
\end{tabular}

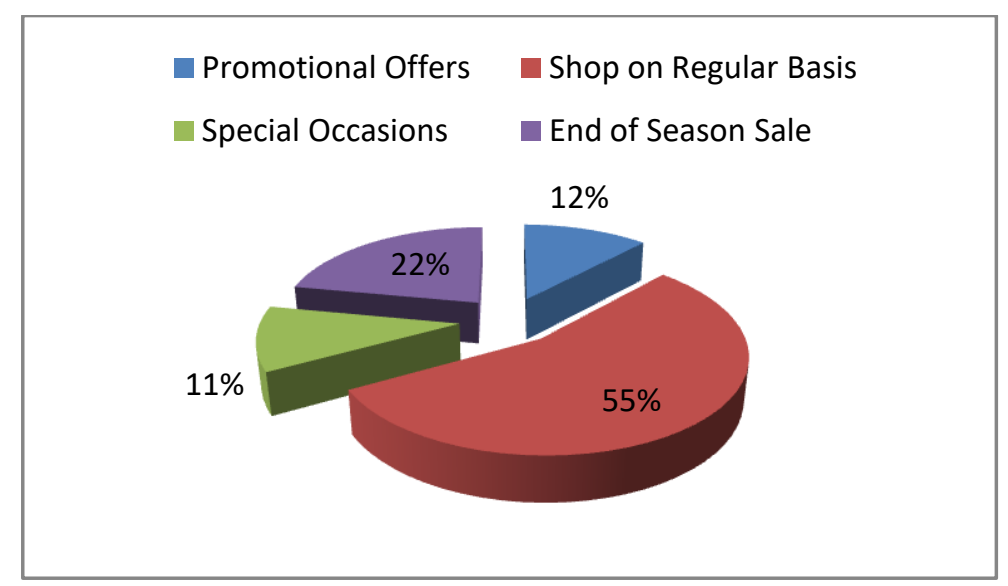

Inference: Majority of the respondents are regular shoppers who generally do not wait for End of Season Sale \& Offers. This is an indicator of loyalty towards Shoppers Stop.

5) Do you think that Shoppers Stop fulfills all your shopping needs?

\begin{tabular}{|l|l|l|}
\hline Responses & No. of Respondents & Percentage \\
\hline Yes & 100 & $94 \%$ \\
\hline No & 1 & $1 \%$ \\
\hline Can't Say & 5 & $5 \%$ \\
\hline Total & $\mathbf{1 0 6}$ & $\mathbf{1 0 0 \%}$ \\
\hline
\end{tabular}




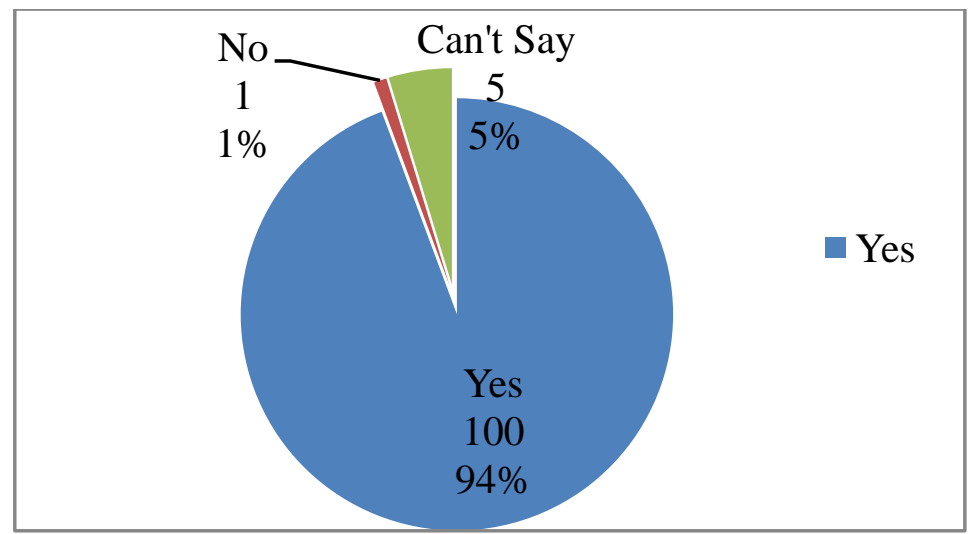

Inference: Majority of respondents (94\%) said that Shoppers Stop fulfils all their shopping needs.

6) Do you think that Shoppers Stop provides expected shopping experience?

\begin{tabular}{|l|l|l|}
\hline Responses & No. of Respondents & Percentage \\
\hline Yes & 95 & $89 \%$ \\
\hline No & 6 & $6 \%$ \\
\hline Can't Say & 5 & $5 \%$ \\
\hline Total & $\mathbf{1 0 6}$ & $\mathbf{1 0 0 \%}$ \\
\hline
\end{tabular}

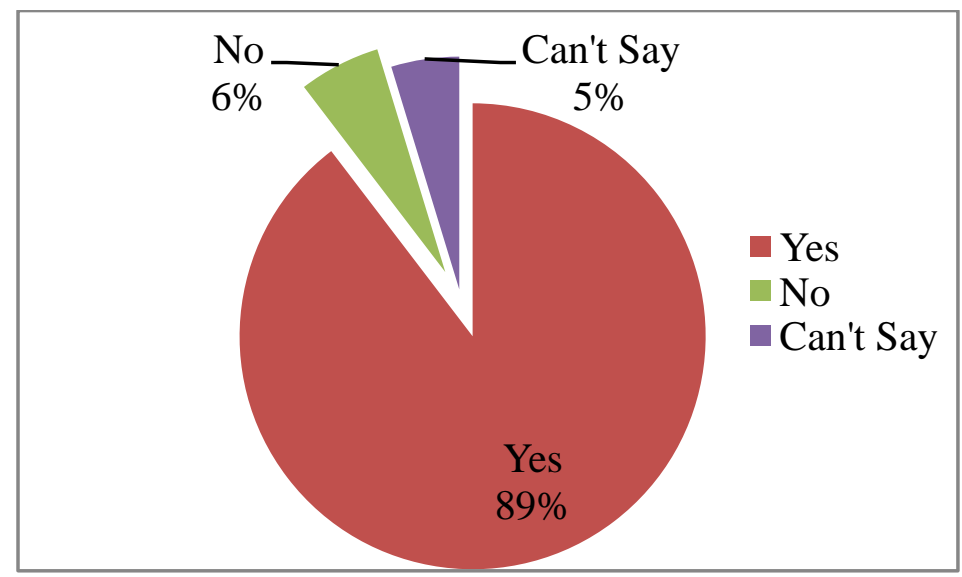

Inference: The shopping experience at Shopper Stop has been found to be satisfactory as majority (89\%) of the respondents think that Shoppers Stop offers the Shopping experience as expected by them. Here one need to note that, meeting the shopping "needs" and fulfilling the expected shopping experience are essentially two different things.

7) Have you enrolled for the "First Citizen" programme?

\begin{tabular}{|l|l|l|}
\hline Responses & No. of respondents & Percentage \\
\hline Yes & 91 & $86 \%$ \\
\hline No & 15 & $14 \%$ \\
\hline Total & $\mathbf{1 0 6}$ & $\mathbf{1 0 0 \%}$ \\
\hline
\end{tabular}




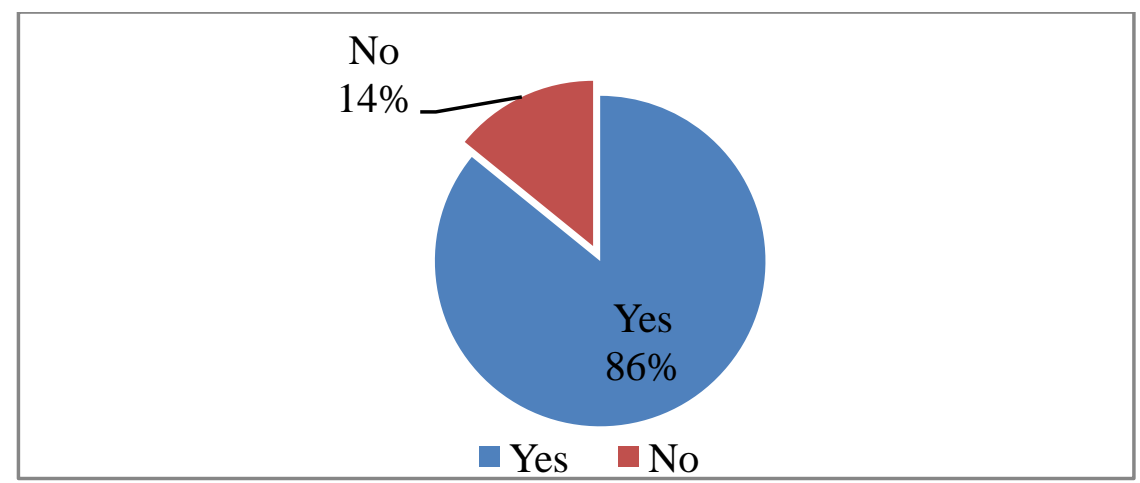

Inference: $86 \%$ of respondents were enrolled with first citizen loyalty programme.

8) If yes, which is that variant of "First Citizen Programme", you are member of?

\begin{tabular}{|l|l|l|}
\hline Responses & No. of Respondents & Percentage \\
\hline Classic Moments & 42 & $46 \%$ \\
\hline Silver Edge & 34 & $37 \%$ \\
\hline Golden Glow & 15 & $17 \%$ \\
\hline Total & $\mathbf{9 1}$ & $\mathbf{1 0 0 \%}$ \\
\hline
\end{tabular}

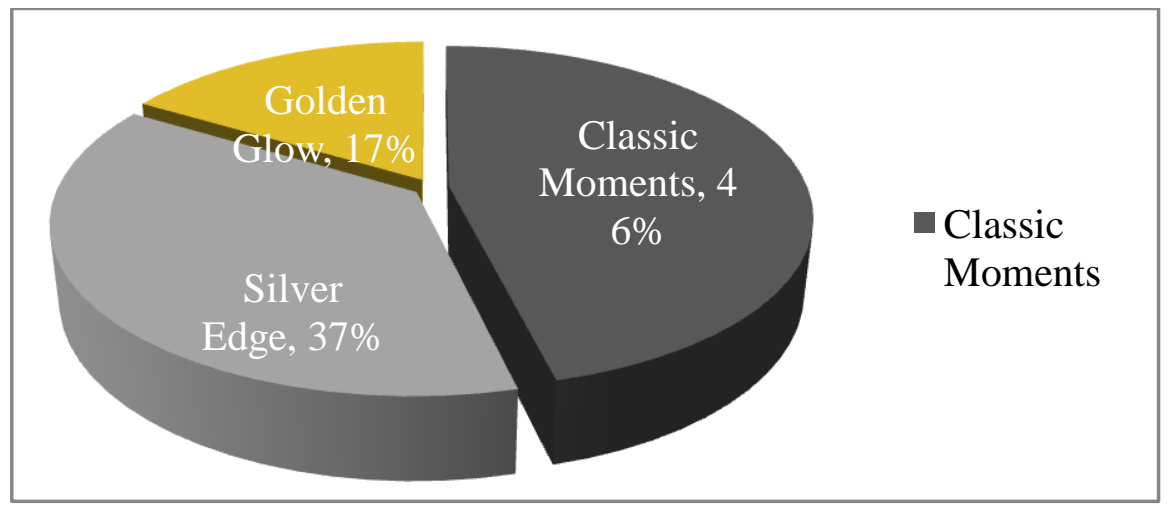

Inference: Majority number of respondents was enrolled for the Classic Moments card

9) Would you like to recommend others to shop at Shopper's Stop?

\begin{tabular}{|l|l|l|}
\hline Responses & No of Respondents & Percentage \\
\hline Yes & 105 & $99 \%$ \\
\hline No & 1 & $1 \%$ \\
\hline Total & $\mathbf{1 0 6}$ & $\mathbf{1 0 0 \%}$ \\
\hline
\end{tabular}




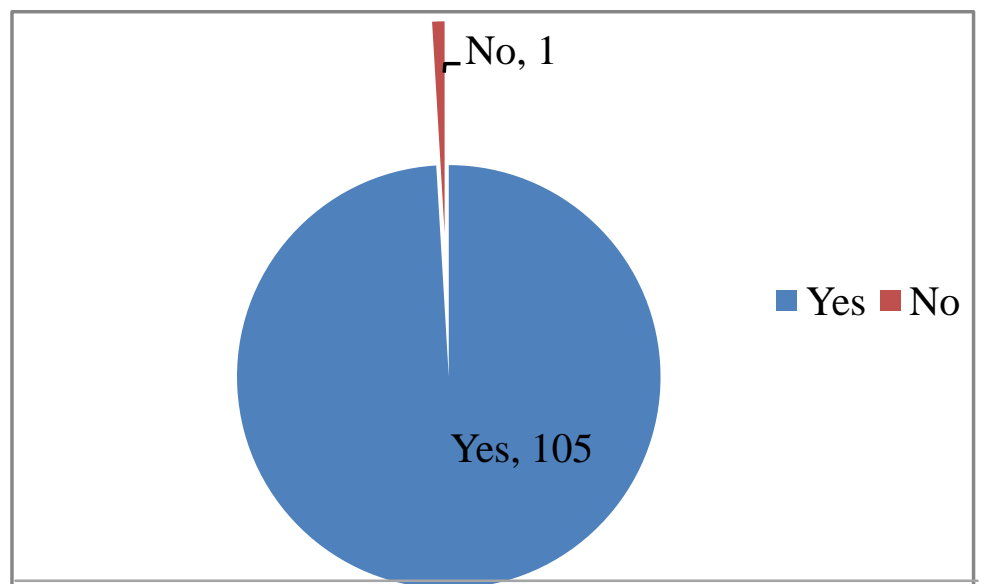

Inference: It is observed that almost all the respondents would like to recommend Shoppers stop to others. This is very good indicator of loyalty towards Shoppers Stop.

\section{0) General Loyalty}

A) I visit stores frequently which offer good shopping atmosphere and ambience

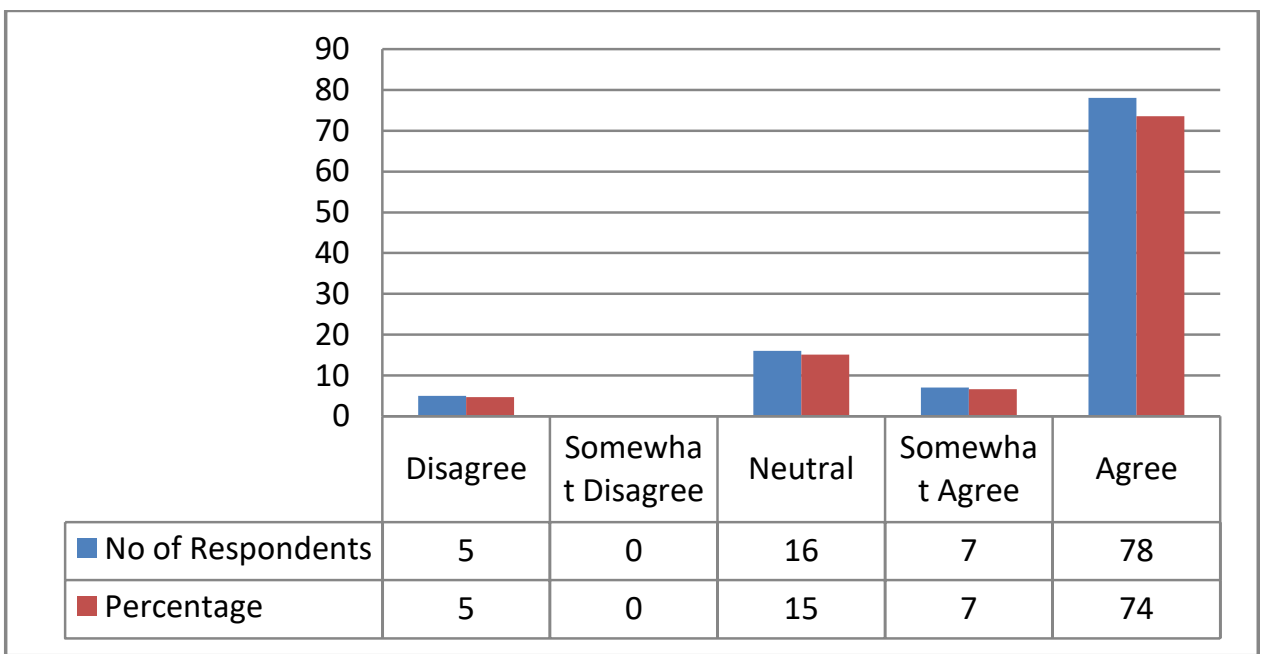

\section{B) I visit Stores frequently that have a strong brand image}

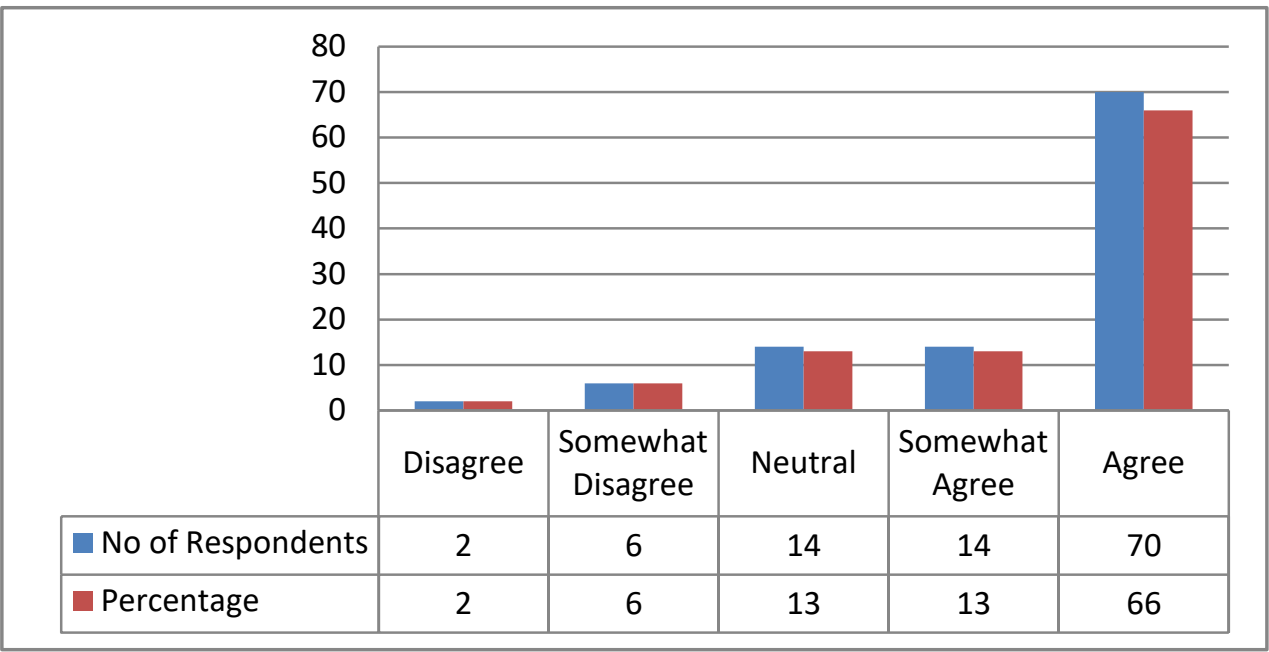


C) I visit stores frequently which offer trendy \& fashionable Private Label Brands on regular basis

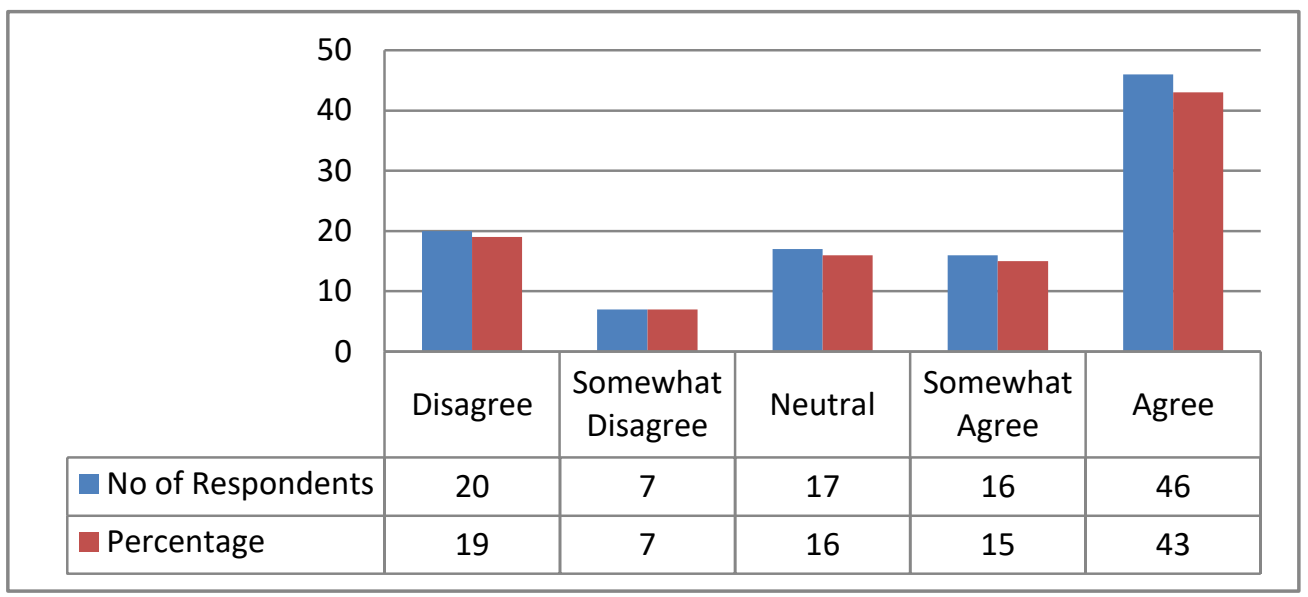

D) I visit stores that are conveniently located from my place on regular basis.

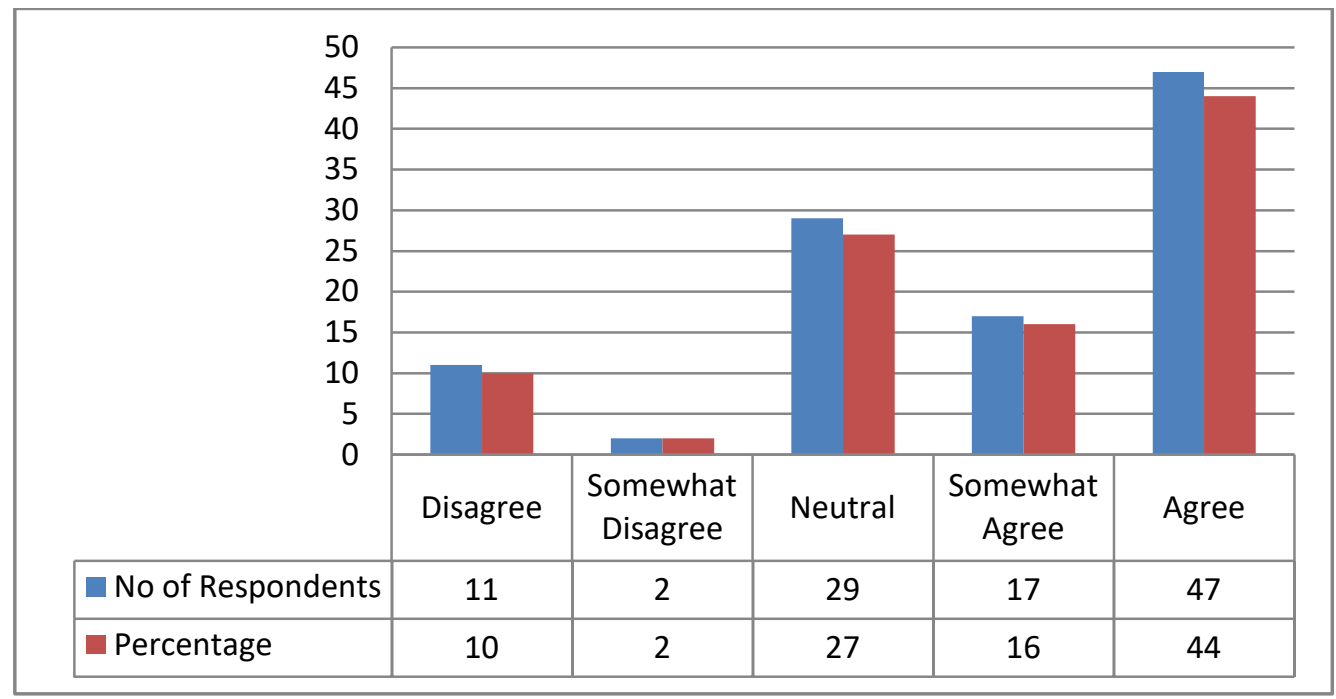

E) I frequently shop at the stores which offer attractive loyalty benefits in the form of points and exclusive offers

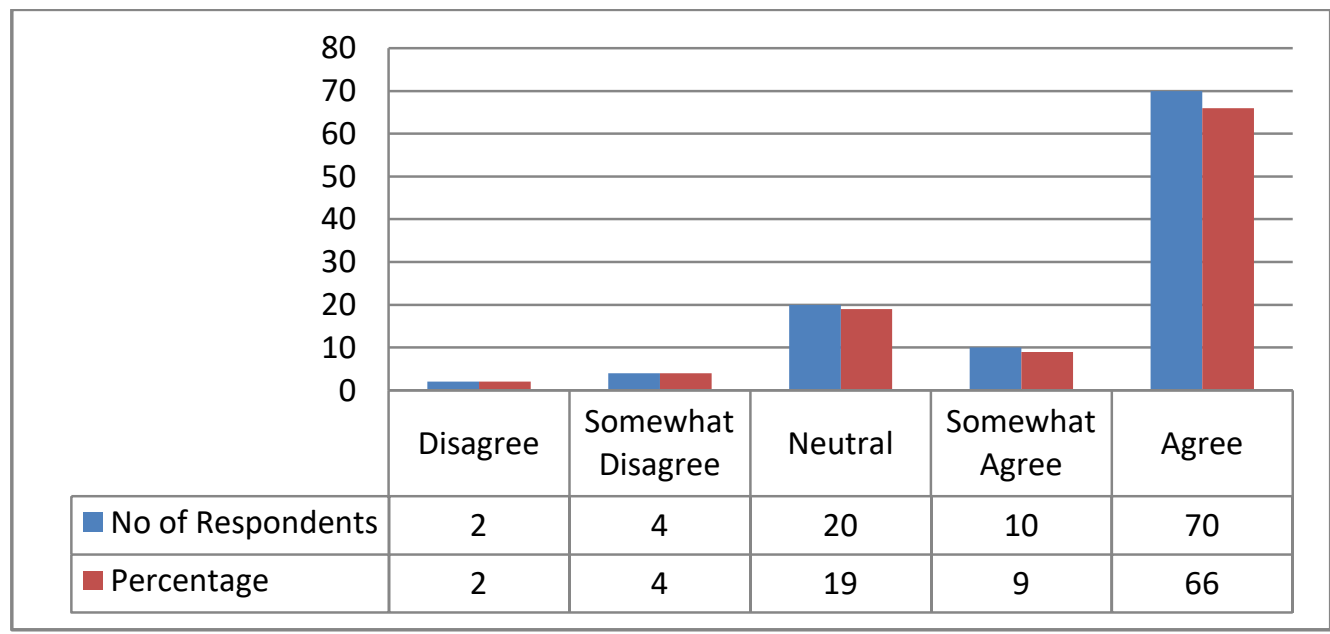




\section{Findings}

- It is also found that along with Shoppers Stop, large proportion of shoppers also shop at stores of other retailers like Lifestyle, Central and Pantaloons. Lifestyle International is the leading competitor for Shoppers Stop.

- Higher percentage of respondents shop at Shoppers on regular basis which is a very positive indicator of loyalty and satisfaction.

- It is observed that many times though a fashion retailer satisfies the needs of the shopper but it is also equally essential to fulfill the expected shopping experience in the same degree.

- Though all the five factors considered in this study play crucial role in enhancing loyalty behavior of the shoppers, if we do comparative analysis among them; shopping atmosphere/ambience is the most influential factor and the trendy \& fashionable private label brands are the least influential one. The other factors like brand image, loyalty programme and location stood at $2^{\text {nd }}, 3^{\text {rd }}$ and $4^{\text {th }}$ position respectively as per their influence.

\section{Managerial Implications-}

- There is majority of customers who shop at Shoppers Stop irrespective of promotional offers and also there is significant number of customers those shop with other leading retailers. This strongly indicates that, fashion retailers need to focus on factors like visual merchandising, store ambience and loyalty programmes in order to enhance the shopping experience and hence the repeat visits/purchase. It can also be justified with the fact that, in case of some respondents, their shopping needs are getting fulfilled but the expectation regarding the shopping experience is not met fully. Here it observed that consumers still prefer to touch, feel and the products before buying, implying therefore that an online-only model is not enough.

- Customer loyalty program's properties (loyalty program distinctiveness and identity relevance) influence consumers' attitudinal and relational responses in forming a relationship between the consumer and the retailer. It is also observed that the identity congruence evoked by the loyalty program influences consumers' favourable responses to the retailer such as attitude toward the store, satisfaction with the store, and hence the loyalty behaviour.

- Private label brands act as point of differentiation for retailers vis-a-vis the competition. They attract the shoppers by virtue of their exclusivity and drive the loyalty behaviour.

- Hence on the basis of findings it can be suggested that, the fashion retailers need to focus on increasing loyalty programme membership in order to increase the ticket-size which eventually increase the frequency of visits as the benefits will also be more for customers.

- In order to enhance the customer engagement the department based fashion retailers need to incorporate attractive loyalty benefits for both transactional and non-transactional actions.

- Bringing the design-patterns that will appeal to the youngsters and millennials as PLBs can act as a strategic factor to create differentiation and hence used to increase the loyalty behaviour of the customers.

- By focusing on various critical elements like visual merchandising and store ambienceatmosphere, departmental stores like Shoppers Stop can enhance the shopping experience.

\section{$\underline{\text { References }}$}

Areni, C. S., \& Kim, D. (1993). The Influence of Background Music on Shopping Behavior: Classical Versus Top-Forty Music in a Wine Store. Advances in Consumer Research, 20, 336-340. https://doi.org/http://acrwebsite.org/volumes/7467/volumes/v20/NA-20

Bellizzi, J. A., \& Hite, R. E. (2006). Environmental color, consumer feelings, and purchase likelihood. Psychology \& Marketing, 9(5), 347-363. https://doi.org/10.1002/mar.4220090502 
Bitner, M. J. (1992). Servicescapes: The Impact of Physical Surroundings on Customers and Employees. Journal of Marketing, 56(2), 57-71. https://doi.org/10.2307/1252042

Britt, S. H. (1967). Consumer Behavior and the Behavioral Sciences: Theories and Applications. John Wiley \& Sons, New York.

Buttle, F. (1996). Relationship Marketing: Theory and Practice. SAGE.

Chaudhary, P. (2015). Exploring retailer's perspectives to understand the impact of Privet Label Brands on retailer's perceived bargaining power and consumer's patronage loyalty behavior towards retailers. International Journal in Management and Social Science, 3(2), 1-11.

Chaudhary, P. (2016). Retail Marketing in the Modern Age (1st ed.). SAGE Publication Inc.

Chaudhary, P., \& Jadhav, R. (2014). Visual Merchandising in retailing: Influencing consumer buying behavior towards apparels with special reference to Pune city in India. International Journal of Marketing and Technology, 4(5), 74-94.

Davey, N. (2014, May). Emotional vs transactional loyalty: Is it more important to win hearts or minds? Retrieved from http://www.mycustomer.com/experience/loyalty/emotional-vs-transactionalloyalty-is-it-more-important-to-win-hearts-or-minds

Gundala, R. R., Jack, A. L., \& Gomes, R. R. (2012). Do loyalty schemes really create loyalty? Evidence from Trinidad's supermarket retail sector. International Journal of Business, Marketing, and Decision Sciences, 5(2), 35+.

Gupta, M. (2016, February 5). The business of private labels in Indian retail [The Economic TimesIndiaretailing Bureau]. Retrieved from http://www.indiaretailing.com/2016/05/02/fashion/thebusiness-of-private-labels-in-indian-retail/

Hancock, J. (2009). Brand/Story: Ralph, Vera, Johnny, Billy, and Other Adventures in Fashion Branding. New York: Fairchild Books.

Kim, B.-D., Shi, M., \& Srinivasan, K. (2001). Reward Programs and Tacit Collusion. Marketing Science, 20(2), 99-120. https://doi.org/10.1287/mksc.20.2.99.10191

Kotler, P. (1973). Atmospherics as a Marketing Tool. Journal of Retailing, 49(4-Winter), 48-61.

Lacey, R., \& Sneath, J. Z. (2006). Customer loyalty programs: are they fair to consumers? Journal of Consumer Marketing-Emerald Group Publishing Limited, 23(7), 458-464. https://doi.org/http://dx.doi.org/10.1108/07363760610713000

Leszczyc, P. T. L. P., Sinha, A., \& Timmermans, H. J. P. (2000). Consumer Store Choice Dynamics: An Analysis of the Competitive Market Structure for Grocery Stores. Journal of Retailing; Fall2000, 76(3), 323-345. https://doi.org/http://dx.doi.org/10.1016/S0022-4359(00)00033-6

Levy, M., Weitz, B., \& Pandit, A. (2008). Retailing Management (6th ed.). Tata McGraw Hill.

Machleit, K. A., Kellaris, J. J., \& Eroglu, S. A. (1994). Human versus spatial dimensions of crowding perceptions in retail environments: A note on their measurement and effect on shopper satisfaction. Marketing Letters, 5(2), 183-194. https://doi.org/10.1007/BF00994108

Mägi, A. W. (2003). Share of Wallet in Retailing: The Effects of Customer Satisfaction, Loyalty Cards and Shopper Characteristics. Journal of Retailing, 79(2), 97-106. https://doi.org/10.1016/S00224359(03)00008-3

Narasimhan, T. E. (2016, February 28). The mother of all brands. Business Standard. Retrieved from http://www.business-standard.com/article/management/the-mother-of-all-brands116022800623_1.html

Sachdev, P. (2016, May 5). New challenges that retailers must tackle. The Hindu Business Line. Retrieved from http://www.thehindubusinessline.com/catalyst/new-challenges-that-retailers-musttackle/article8557091.ece

Sharp, B., \& Sharp, A. (1998). Loyalty Programs and their Impact on Repeat-Purchase Loyalty Patterns: a replication and extension. Marketing Science Centre, Adelaide, Australia. Retrieved from http://www.nessvalley.com/resources/6076.PDF

Shirkhande, G. (2016, February 5). The business of private labels in Indian retail [The Economic TimesIndiaretailing Bureau]. Retrieved from http://www.indiaretailing.com/2016/05/02/fashion/thebusiness-of-private-labels-in-indian-retail/

Turley, L. W., \& Milliman, R. E. (2000). Atmospheric Effects on Shopping Behavior: A Review of the Experimental Evidence. Journal of Business Research, 49, 193-211.

Wilson, S. (2003). The effect of music on perceived atmosphere and purchase intentions in a restaurant. Psychology of Music- Society for Education, Music and Psychology Research, 31(1), 93-112. 